\title{
COMMENTARY
}

\section{THE INFLUENCE OF GEOGRAPHY IN ASYMMETRIC CONFLICTS IN NARROW SEAS AND THE HOUTHI INSURGENCY IN YEMEN}

\author{
Khaldoon Ahmed Abdulla and Jatswan S. Sidhu
}

\begin{abstract}
This commentary discusses the impact of geography in asymmetric warfare in order to analyze how inferior side acting from a geographical advantage can cast a challenge to the superior party in conflict. As such, the paper focuses on the context of narrow seas, the opportunities and challenges that the geographical configuration of the seas creates for adversaries, its impact on their capabilities and influence on their choices. Subsequently, it attempts to illustrate the role of geography in enhancing the efficiency of small arms tactics and unconventional warfare at seas, henceforth, realizing the spatial factor behind the rise of non-state actors as a major threat in maritime security. The commentary then discusses the case of the Houthi insurgency in Yemen to empirically explore their utilization of the geographical location of the country at the southern entrance of the Red Sea, near Bab el-Mandeb Strait in order to execute sporadic military operations against the more superior coalition led by Saudi Arabia.
\end{abstract}

Keywords: Geopolitics, maritime security, Narrow Seas, asymmetric warfare, Red Sea, Yemen, Houthis

\section{THE INFLUENCE OF GEOGRAPHY IN NARROW SEAS}

In contemporary studies of international relations, the discussion is usually dominated by the paradigm of the functional structure of the international system with anarchy as its central concept. Thereupon, the assessment of actors' capabilities is tied to the dynamic factors such as military might, economic growth, and manpower, thus leading to a linear comparison of the distribution of capabilities among the adversaries (Waltz, 1979). This falls short in analyzing how smaller actors can in some cases cause a major challenge for the more superior actor. Kaplan in his book The Revenge of Geography aims to revive the geopolitical tradition in international politics and asserts that the evident driving force in international politics lies in the geographical factor, which provides the framework of analysis and insights into past and future conflicts. He adds that any analysis that neglects geography will backfire (Kaplan, 2012).

By the same token, Gray and Sloan emphasizes on the dominance of geography among other factors. Using the analogy of chicken curry, Gray explains that geography is like curry where the taste will be found in every ingredient in the dish. In other words, the influence of geography is manifested in terms of challenges and opportunities that impact the entire political process and the choices of actors, the making of their policies, strategies, and tactics (Gray \& Sloan, 2013: 170). In that sense, the capabilities of actors will always be refrained to the spatial context in which they are being practiced and given that, an inferior actor with a geographical advantage can gain the upper hand in conflict against a superior opponent facing geographical obstacles. 
In this context, narrow seas come as one of the most significant spaces where the impact of geography is vividly demonstrated. Owing to the fact of their unique configuration, being trapped between continental masses and accessible through straits, the strategy and operations in narrow seas are more sensitive to the small frictions of the geographical factors (Vego, 2003: 16). Indeed, according to Corbett most of the decisive attacks against shipping are usually carried in narrow seas, not open oceans (Till, 1984: 42). For instance, oceans are perceived as open highways and pathways for global transport carrying more than 80 percent of global trade (Luft \& Korin, 2004). Compared to land, oceans provide safer routes for several reasons. First, due to the massive width of oceans, maritime targets are sparse, which significantly reduces the number of attacks. Second, the absence of terrains and obstacles provides better surveillance for ships and less coverage for the attackers, consequently, a better chance for maneuverability for the former (Parfomak \& Frittelli, 2009). However, in narrow seas those factors are reversed. This is because straits are bottlenecks for all naval and commercial ships (Vego, 2003: 51) and therefore acts as focal points for engagement (Till, 1984: 187). Additionally, due to the narrowness of strait, larger ships will have to reduce its speed to ensure safe passage, which makes it an easy target (Joyner, 2009). Consequently, command over the strait provides the controller with the opportunity to block the adversary regardless of the difference in their capabilities. For instance, in World War I, Turkey managed to block the Allies by lying mines in the Dardanelles and managed to isolate the Russian navy from its western allies (Vego, 2003: 166).

Furthermore, the adjacency of the coast to maritime routes creates other limitations and opportunities as well. Notably the closeness to brown waters allows small boats to confront the larger ships that sail in limited space of water with sufficient depth. Usually the attacks from the small boats are carried by militants using limited arms such as machine guns and anti-armor weapons that can be carried by an individual like shoulder-fired RPG. For instance, in 2013, an Al-Furqan group in the Sinai Peninsula managed to attack two commercial ships passing through the Suez Canal using RPG (McNicholas, 2016: 263). Beside commercial targets, small boats tactic are proven to be efficient even against military vessels. In 2000, the Al-Qaeda conducted a suicide bombing operation against United States (U.S.) destroyer USS Cole near the Gulf of Aden using a speedboat loaded with explosives. The operation resulted in the killing of 17 of the destroyer crew and caused serious damage to the body of the vessel (McNicholas, 2016: 263).

What adds insult to injury is that in many cases these kinds of attacks will occur within a state's local waters, which creates legal issues in terms of the permissibility to use power and conduct military operations against attackers. For example, the International Maritime Organisation (IMO) limits piracy to attacks committed in high seas and this definition created a legislative dilemma for international community especially pertaining to actions against Somalia piracy (Joyner, 2009). Furthermore, the short distance between coasts and waterways allows the aggressor to attack naval and commercial vessels using weapons fired from land such as gun batteries and coastal missiles (Vego, 2003: 167) or even by indirect war tactics that does not include confrontation, like mine laying. This was seen during the Arab-Israeli war in 1973, when the Egyptians executed a naval blockade against the Israelis in the Red Sea, mining the Gulf of Aqaba and the waters fronting the Sharm elSheikh port (Vego, 2003: 241). 
Under those circumstances, the impact of the geographical configuration of narrow seas gives weight to small arms tactics to create a major impact if it is executed from a point of geographical advantage. Consequently, this has given rise to non-state actors posing a major security challenge at seas. Indeed the inclusion of the concept of maritime security in the political agendas and policies was a direct consequence of the rise of threats from non-state actors. For example, the U.S. adopted the aspects of maritime security after 9/11 due to fears of terrorism at sea. The Bush administration introduced the National Strategy for Maritime Security in 2005 as part of the U.S.' global war on terrorism (Parfomak \& Frittelli, 2009). Yet, the biggest challenge for maritime security was in 2008 when there was a dramatic rise in piracy in the Gulf of Aden (Bueger, 2015). From a thematic perception, the types of non-state actors at seas can be classified to mainly four categories. The first category are smugglers while the second are pirates conducting armed robbery against ships. The third are terrorists who might conduct operations at sea to advance their cause and/or intimidate their opposition (Edgerton, 2013), and lastly are insurgents who, similar to terrorists, carry out military operations against governmental and military vessels (Møller, 2009).

\section{THE RED SEA AND THE HOUTHI INSURGENCY IN YEMEN}

Empirically, the study of the Red Sea provides an insight on the workability of geography in asymmetric contestations. The Red Sea is one of the busiest waterways in global shipping as it provides a short passage between the east and west. Since the beginning of the millennium, the Red Sea has been a hotspot for maritime security concerns, which were mostly confined near the Bab el-Mandeb Strait, with threats coming from the rise of piracy, smuggling activities and terroristic attacks. These challenges were mainly the result of a spillover from two fragile (failed) states bordering the strait, Somalia and Yemen. In fact, the current civil war in Yemen has created a new threat to the Red Sea shipping lines, with the Houthi militants successfully managing to execute several operations at sea.

The Red Sea is a strategic waterway that lies between Europe, Africa and Asia, bordering the Arabian Peninsula and East Africa in almost a straight line that is 1932 kilometers in length, and with a width that ranges from 306 kilometers at Massawa, to less than 30 kilometers at the Bab el-Mandeb Strait. Meanwhile, the mean depth of the sea is around 500 meters. The sea opens to the Mediterranean Sea in the north through Suez Canal, and to the Gulf of Aden in the south through Bab el-Mandeb Strait, thus linking Europe and Asia. Both sea exits, namely the Bab el Mandeb and the Suez Canal, are counterparts for two other strategic global chokepoints, namely the Straits of Malacca (a main shipping lane for the flow of trade and resources between East Asia and Europe) and the Hormuz Strait (from where the Gulf oil flows to the west). Moreover, in comparison to other maritime routes, the Red Sea provides the shortest route that connects the Indian Ocean with the Mediterranean Sea as well as the Atlantic Ocean, thus making it the main shipping line for the transportation of oil to Europe. Besides its economic significance, the Red Sea is also a short line of communication for navies plying between the east and the west, with the distance between the lines of communications being an impactful factor in the naval strategic and operational aspects (Al-Anazi, 2001). 
The Bab el-Mandeb, translated as the gate of tears from Arabic, acts as the bottleneck and the southern entrance of the Red Sea with a width of less than 30 kilometers, which is divided by Perim Island into two channels (Al-Yadomi, 1991). For centuries, the strait had been an active route for trade. Goods coming from the East were transported through the Red Sea to Egypt, and then loaded onto caravans before being shipped to Europe through the Mediterranean Sea. When the Suez Canal was opened in 1896, the strategic importance of the Red Sea and the Bab el- Mandeb became even greater (Al-Yadomi, 1991). Contemporarily, the strategic importance of Bab elMandeb lies in its location between two important waterways, the Red Sea and the Indian Ocean. Further, it has gained increased importance due to the resources in the region, namely oil in the Arabian Peninsula and the Persian Gulf (Remnek, 1990). Around 20 thousand ships pass through the strait annually, carrying an average of 3.4 million barrels of oil per day (Anderson, 2013: 25-26).

Yemen shares the strait alongside Eretria and Djibouti. As a signatory to the United Nations Convention on the Law of the Sea (UNCLOS) in 1987, Yemen enjoys 12 nautical miles of territorial waters in the Bab el-Mandeb (Emmerson \& Stevens, 2012). The weakness of Yemen's central government has allowed several non-state actors to utilize the strategic location of the country to conduct illegal activities in the Red Sea. These include human trafficking, weapons smuggling and terrorist attacks. In 2014, the Houthi militia, an Iranian-backed militia originally from the Saada governorate in north Yemen, took over the capital and started a military campaign in which it managed to capture the main ports and cities along the Yemeni west coasts. With an Iranian-backed militia commanding the Red Sea, the civil war in Yemen soon escalated into a regional conflict in March 2015, with a direct Saudi-led military intervention (Hokayem \& Roberts, 2016).

While the better-armed coalition adopted conventional tactics, which included around 170 fighting aircrafts (Knights \& Mello, 2015), the inferior Houthis favored an indirect approach to war and guerrilla tactics that heavily depended on the geographical factors of the country. In fact, it was just a matter of time when the battles on the ground began extending into the waters, as the Houthis started executing operations against coalition ships in the Red Sea. The maritime insurgency took the form of sporadic attacks, which were executed using unconventional tactics, such as drone boats, cruise missiles, speedboats and mines (Knights \& Mello, 2015).

Utilizing the narrowness of the sea, the Houthis managed to successfully fire cruise missiles from the coast against military vessels and oil cargoes. The first attack was in October 2016 against the Emirati vessel HSV-2 Swift, using Chinese built C-802 anti-ship missile and causing serious damage to the vessel (Stratfor, 2016). Although a similar attack was repeated against a U.S. destroyer, the missile was intercepted before reaching its target (Stratfor, 2016). In addition to naval vessels, the Houthis also conducted cruise missile attacks against commercial targets, mainly Saudi oil cargoes, thus driving the Saudis to suspend their oil exports through the Bab el-Mandeb. This achievement was even praised by General Qasem Soleimani from Iran's Revolutionary Guard who used the incident to emphasize and highlight Iranian presence in the Red Sea that was already posing a threat to the U.S presence in the region (Iran Press, 2018). Even though the shipping of oil was resumed, the Houthis managed to send a clear message about their capabilities to the coalition. 
Besides that, the Houthi militia used drone boats to attack ships and marine infrastructures. In June 2016, a self-guided drone boat loaded with explosives was used to attack a Saudi loading facility in Jizan in the southern part of Saudi Arabia, though it proved unsuccessful (Knights \& Nadimi, 2018). Nonetheless, in July 2017, the Houthis managed to hit the wharf of the Mokha port in Yemen, successfully hitting a United Arab Emirates' vessel that was decked at the port (Al Jazeera, 2017). However, the Saudi-led coalition brushed the incident off as only resulting in minor damages (KUNA, 2017). Moreover, reports indicated that the Houthis had also laid mines in the Red Sea, which floated to tens of kilometers around Bab el-Mandeb and the Gulf of Aden. The 2018 annual report on Yemen by the United Nations Panel of Experts, estimated that a total of 44 mines were found in the area in 2017, with four incidents of detonation (Knights \& Nadimi, 2018).

Altogether, while the distribution of capabilities between the Saudi-led coalition and the Houthi militia varies significantly, the geographical factors embodied in the configuration of the Red Sea, and Yemen's adjacency to Bab el-Mandeb Strait have provided an advantage for the Houthis which has facilitated the execution of several sporadic attacks against the coalition ships using small arm tactics and unconventional weapons, thus causing a spillover of the insurgency into the sea.

\section{CONCLUSION}

In sum, while the balance of power between actors is perceived through the difference in their respective capabilities, geography represents the physical and spatial dimension in which those capabilities will be applied. The impact of geography is manifested through advantages and limitations that will influence the choices of the actors and their efficiency. Consequently, in asymmetric warfare, the geographical factors can grant an advantage to the weaker side. Indeed, in narrow seas, the configuration of the waterways and the coasts, limits the speed, surveillance and maneuverability of the larger ships and navies, which have to pass through straits, narrow paths and sometimes, local waters. On the other hand, this has given an advantage for the actors positioned within states fronting the strategic points. For instance, the straits have not only contributed in increasing the number of ships that can be targeted, but also their vulnerability to attacks. Moreover, the limited distance between the coasts and shipping lines allows for conducting of attacks by unconventional means such cruise missiles fired from land, machine guns and anti-tanks missiles operated on speed boats, as well as the use of drone boats, and suicide bombers. As a consequence, this has allowed nonstate actors to become a security threat in the maritime domain. In the context of the Red Sea, the Houthi insurgency in Yemen has managed to utilize the geographical location of the country near Bab el-Mandeb Strait to conduct sporadic attacks, mainly against the Saudi-led coalition. This evidently illustrates the workability of geography as an advantage for inferior actors in asymmetric warfare.

\section{REFERENCES}

“A New Threat to Red Sea Shipping,” Austin, TX: Sratfor, 5 October 2016, $<$ https://worldview.stratfor.com/article/new-threat-red-sea-shipping $>$

\section{Al-Anazi, T., Strategic Importance of the Red Sea, Pennsylvania: US Army War} College, 2001. 
Al-Yadomi, H., The Strategic Importance of Bab Al-Mandab Strait. Pennsylvania: US Army War College, 9 April 1991.

Anderson, E. W. (2013). Global Geopolitical Flashpoints: An Atlas of Conflict. Abingdon: Routledge.

Bueger, C. (2015). What is maritime security?. Marine Policy, 53, 59-164.

Edgerton, M. (2013). A Practitioner's Guide to Effective Maritime and Port Security. Hoboken: John Wiley \& Sons.

Emmerson, C. and P. Stevens, P. (2012). Maritime Choke Points and the Global Energy System: Charting a Way Forward. Briefing Paper, London: Chatham House. Gray, C. S. and Sloan, G. (2013). Geopolitics, Geography and Strategy. New York: Routledge.

“General Soleimani: Red Sea no longer safe for US presence," Iran Press, 26 July 2018, $<$ https://www.google.com/search?q=Suleimani\%3AThe+Red+Sea+is+Longer+Safe+ with+US+Presense\&rlz=1C1CHWA_enMY650MY650\&oq=Suleimani\%3AThe+Re $\mathrm{d}+$ Sea+is+Longer+Safe+with+US+Presense\&aqs $=$ chrome..69i57j69i58.702j0j8\&sour ceid $=$ chrome \&ie $=$ UTF- $8>$

Hokayem, E. and Roberts, D. B. (2016). The War in Yemen. Survival, 58, 6, 157-186.

"Houthis claim attack on UAE ship off Yemen's west coast," Al Jazeera, 29 July 2017, <https://www.aljazeera.com/news/2017/07/houthis-claim-attack-uae-shipyemen-west-coast-170729184615831.html>

"Houthi Militia Targets Mokha Port Using Bombed Boat," KUNA, 29 July 2017, $<$ https://www.kuna.net.kw/ArticleDetails.aspx?id=2626605\&language $=$ en $>$

Joyner, C. (2009). Navigating Troubled Waters: Somalia, Piracy, and Maritime Terrorism. Georgetown Journal of International Affairs, 10, 2, 83-91.

Kaplan, R. D. (2012). The Revenge of Geography. New York: Random House.

Knights, M. and F. Nadimi (2018, 27 July). Curbing Houthi Attacks on Civilian Ships in the Bab al-Mandab. Washington DC: The Washington Institute,

$<$ https://www.washingtoninstitute.org/policy-analysis/view/curbing-houthi-attackson-civilian-ships-in-the-bab-al-mandab>

Knights, M. and A. Mello, A. (2015,11 August). The Saudi-UAE War Effort in Yemen (Part 2): The Air Campaign. Washington DC: The Washington Institue, $<$ https://www.washingtoninstitute.org/policy-analysis/view/the-saudi-uae-war-effortin-yemen-part-2-the-air-campaign>

Luft, G. and A. Korin (2004). Terrorism Goes to Sea. Foreign Affairs, 83, 6, 61-71. 
McNicholas, M. A. (2016). Maritime Security An Introduction (2 ${ }^{\text {nd }}$ Ed.). New York: Elsevier.

Møller, B. (2009). Maritime Terrorism and Naval Strategy. Copenhagen: Danish Institute for International Studies (DIIS).

Parfomak, P. W. and J. Frittelli (2009). Maritime Security: Potential Terrorist Attacks Protection Priorities. Washington DC: Congressional Research Service, The Library of Congress.

Remnek, R. B. (1990). The Strategic Importance of the Bab al-Mandab and the Horn of Africa: A Global Perspective. In D. A. Kom, S. R. Dorr, L. Neysa and M. Slater (eds.). The Horn of Africa and Arabia. Washington DC: Defense Academic Research Support Program and The Middle East Institute, 1-17.

Till, G. (1984). Maritime Strategy in the Nuclear Age (2 $2^{\text {nd }}$ Ed.). London: Macmillan.

Vego, M. N. (2003). Naval Strategy and Operations in Narrow Seas. London: Frank Cass.

Waltz, K. N. (1979). Theory of International Politics. Boston: Addsion-Wesley. 